\title{
Predictive Value of Preoperative Magnetic Resonance Imaging of the Pituitary for Surgical Cure in Cushing's Disease
}

\author{
Cushing Hastalı̆̆ında Pitüiterin Preoperatif Manyetik Rezonans \\ Görüntülemesinin Prediktif Değeri
}

\author{
Przemysław WITEK ${ }^{1,2}$, Grzegorz ZIELINSKI ${ }^{3}$ \\ ${ }^{1}$ Military Institute of Medicine, Department of Endocrinology, Warsaw, Poland \\ ${ }^{2}$ Medical Centre of Postgraduate Medicine, Department of Endocrinology, Warsaw, Poland \\ ${ }^{3}$ Military Institute of Medicine, Department of Neurosurgery, Warsaw, Poland
}

Correspondence address: Grzegorz ZIELINSKI / E-mail: gmz@aster.pl

\begin{abstract}
AIM: Cushing's disease (CD) is caused by ACTH-secreting pituitary adenoma. Transsphenoidal surgery (TSS) is the treatment of choice. CD diagnosis must be based on biochemical confirmation of hypercortisolemia and visualization of pituitary tumor on magnetic resonance imaging (MRI). Diagnostic problems are associated with equivocal or even normal MRI. In such situations, some neurosurgical centers perform a diagnostic sellar exploration. The purpose of this study was to evaluate the relationship between the results of preoperative MRI of the pituitary and efficacy of TSS for CD.
\end{abstract}

MATERIAL and METHODS: A prospective study enrolling 36 consecutive patients with biochemically confirmed CD operated on and then followed up for at least 18 months.

RESULTS: 23 of 36 patients $(63,9 \%)$ were cured. Persistent CD was confirmed in 13 patients $(36,1 \%)$. A difference was demonstrated between both groups with reference to the preoperative MR findings. In the cured group there was a significantly greater number of patients with precisely visualized pituitary microadenoma whereas in the non-cured group there was a significantly greater number of patients with pituitary macroadenoma or equivocal result of MRI $(p=0.036)$.

CONCLUSION: Precise localization of corticotroph microadenoma on the preoperative MRI may be considered as one of predictive factors positively prognosticating cure after TSS for CD.

KEYWORDS: Cushing's disease, Magnetic resonance imaging, Transsphenoidal surgery, Cortisol, Pituitary tumor

öz

AMAÇ: Cushing hastalığının (CD) nedeni ACTH salan pitüiter adenomdur. Tercih edilen tedavi transsfenoidal cerrahidir (TSS). CD tanıSı hiperkortizoleminin biyokimyasal olarak doğrulanması ve manyetik rezonans görüntülemesinde (MRG) pitüiter tümörün görüntülenmesini temel almalıdır. Diagnostik problemler kesin olmayan ve hatta normal MRG ile ilişkilidir. Bu gibi durumlarda bazı nöroşirürji merkezleri diagnostik sellar keşif yapar. Bu çalışmanın amacı, preoperatif pitüiter MRG ile TSS'nin CD açısından etkinlik sonuçları arasındaki ilişkinin değerlendirilmesiydi.

YÖNTEM ve GEREÇLER: Biyokimyasal olarak doğrulanmış ve ameliyat edilmiş CD durumu olan ve sonrasında 18 ay takip edilen arka arkaya 36 hastanın bulunduğu prospektif bir çalışma.

BULGULAR: 36 hastanın 23'ünde $(\% 63,9)$ tam iyileşme görüldü. Devam eden CD 13 hastada $(\% 36,1)$ doğrulandı. İki grup arasında preoperatif MR bulguları açısından bir fark gözlendi. Tam tedavi edilen grupta çok daha fazla sayıda hastada tam olarak görüntülenen bir pitüiter mikroadenom varken tam tedavi edilmeyen grupta çok daha fazla sayıda hastada bir pitüiter makroadenom veya kesin olmayan MRG sonucu vardı $(p=0,036)$.

SONUÇ: Preoperatif MRG'de kortikotrof mikroadenomun tam olarak lokalizasyonu CD için TSS sonrasında tam iyileşme durumunu pozitif olarak etkileyen prediktif faktörlerden biri olarak düşünülebilir.

ANAHTAR SÖZCÜKLER: Cushing hastalığı, Manyetik rezonans görüntüleme, Transsfenoidal cerrahi, Kortisol, Pitüiter tümör 


\section{BACKGROUND}

The hallmark of Cushing's disease is chronic hypercortisolemia caused by excessive, autonomous secretion of corticotrophin (ACTH) by the pituitary adenoma $(1,15)$. Despite the relatively low incidence (estimated at 1 - 3 new cases per million inhabitants per year), the disease constitutes one of the greatest challenges of modern endocrinology and neurosurgery $(11,13)$. Once ACTH-dependent hypercortisolemia is biochemically confirmed, it becomes necessary to perform optimal neuroradiological procedures, aimed at obtaining the most precise visualization of suspicious focal lesion within the pituitary gland.

According to the generally adopted criteria, the magnetic resonance imaging (MRI) is the visualization method of choice in diagnostics of Cushing's disease $(7,14,15)$. Due to the fact that pituitary microadenomas are responsible for more than $80 \%$ of all cases of ACTH -dependent Cushing's syndrome of pituitary origin, the most frequently observed MR image (Figure $1 \mathrm{~A}$ ) displays the focal lesion with the diameter of less than $10 \mathrm{~mm}$, usually hypodense after intravenous contrast (15). Furthermore the corticotroph pituitary microadenomas do not exceed the diameter of $5 \mathrm{~mm}$ even in as much as $50 \%$ of cases. This constitutes the fundamental difficulty in neuroradiological imaging of pituitary corticotrophic adenomas and sometimes makes it necessary to search for indirect features of the presence of pituitary adenoma, such as deviation of the pituitary stalk (Figure 1B) or convex upper surface of the pituitary gland.

The issues presented above clearly make further surgical treatment more difficult to perform. Sometimes they force a neurosurgeon to make an attempt of intraoperative localization of a focal lesion within the pituitary gland. Furthermore, rarely occurring corticotroph pituitary macroadenomas, due to their size and ability to infiltrate surrounding structures (Figure 1C, D), constitute a real challenge for a neurosurgeon, forcing the physician to make technically difficult and risky attempts to relieve compression of the optic chiasm, internal carotid arteries or cavernous sinuses $(9,10,17)$.

Considering the above, it seems that precise, preoperative MR imaging as well as proper interpretation of obtained results may contribute to optimize the principles of diagnostic and therapeutic procedures used in the treatment of this relatively rare but severe and devastating disease. Therefore, the purpose of this study was to prospectively evaluate the importance of preoperative MRI findings for the efficacy of neurosurgical treatment of Cushing's disease.
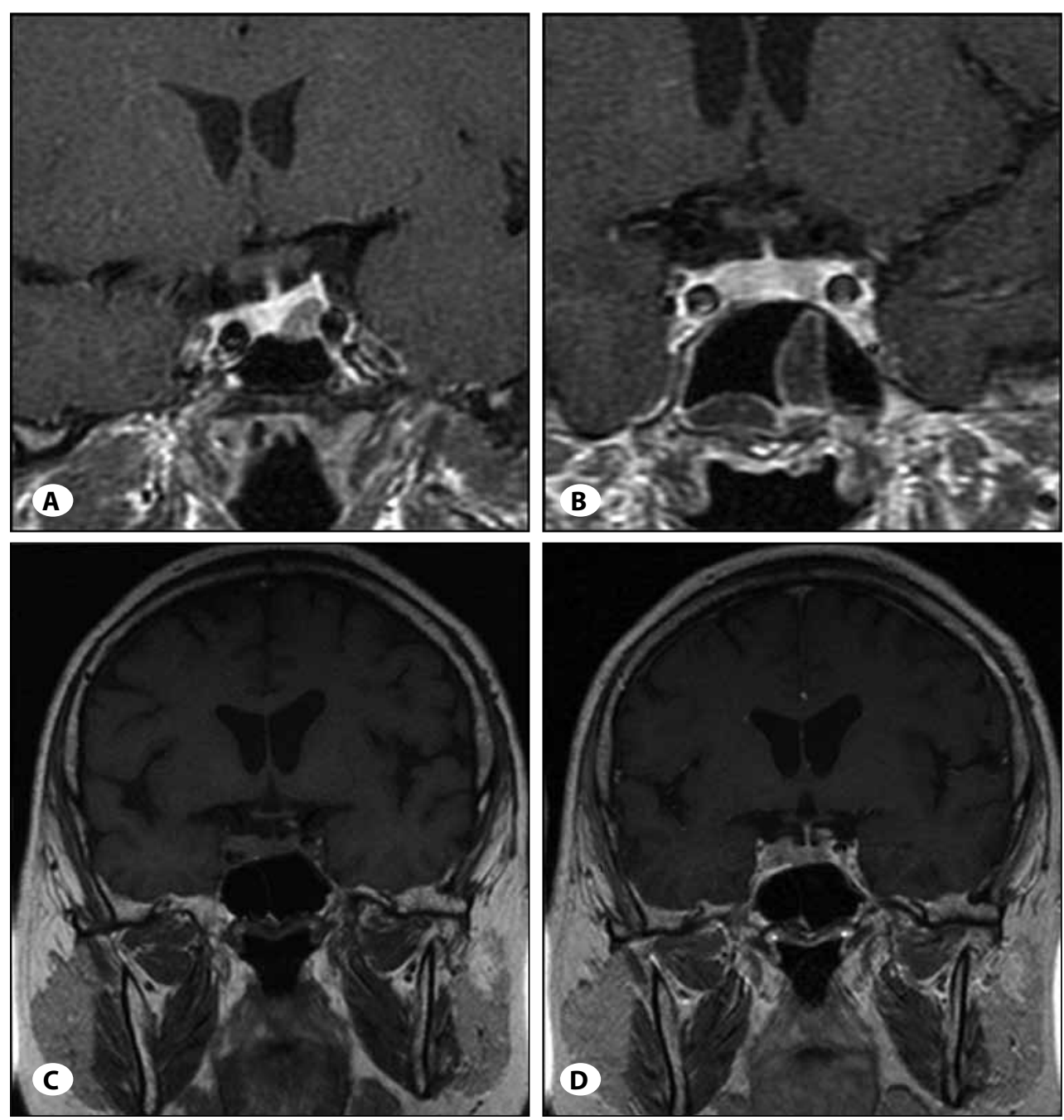

Figure 1: MRI sections from patients with CD (own material) demonstrating:

A) distinct, left-sided pituitary microadenoma (coronal section, post-contrast);

B) indirect features of the presence of microadenoma deviation of the pituitary stalk C - D) pituitary macroadenoma, coronal sections (a. pre-contrast; b. post-contrast) with the infiltration of right internal carotid artery and cavernous sinus). 


\section{MATERIAL and METHODS}

\section{Patient population}

The study population consisted of 36 consecutive patients with Cushing's disease (30 women and 6 men; F:M ratio: 5:1) hospitalized in the Department of Endocrinology from 2005 to 2009. The mean age was $36.3 \pm 12.9$ years (range 17 to 57 years). Following confirmation of $C D$ all patients were operated on by the same neurosurgeon according to an identical surgical protocol.

All patients were informed about the aims and methods of the study. The written informed consent with the signatures was taken. The study protocol was approved by the Bioethics Committee at the Medical Centre of Postgraduate Education.

Clinical course of the disease and preoperative endocrine evaluation

The diagnosis of ACTH - dependent Cushing's syndrome (CS) was made based on the clinical signs and standard hormonal criteria: increased urinary excretion of urinary free cortisol (UFC), the loss of cortisol circadian rhythm (serum cortisol level above $7.5 \mu \mathrm{g} / \mathrm{dl}$ in the late-night hours), increased or detectable level of plasma ACTH at 8.00 and the failure of serum cortisol to suppress to less or equal than $1.8 \mu \mathrm{g} / \mathrm{dl}$ during the low dose dexamethasone suppression test (LDDST; $0.5 \mathrm{mg}$ q.i.d. for 48 hours). The pituitary aetiology of CS was confirmed based on a serum cortisol and UFC suppression greater than $50 \%$ on high dose dexamethasone suppression test (HDDST; $2 \mathrm{mg}$ q.i.d. for $48 \mathrm{~h}$ ) and positive MRI. In case of equivocal results of hormonal assessment and pituitary imaging the diagnosis of Cushing's disease was confirmed by a positive result of stimulation test with intravenous $\mathrm{CRH}$ injection $(100 \mu \mathrm{g})$.

\section{Preoperative MR imaging}

All patients underwent high resolution magnetic resonance imaging of the pituitary-hypothalamic region (SIEMENS Symphony 2004; 1.5 Tesla). The MRI scans were performed before and after intravenous injection of Gadolinium (Gd-DTPA). The presence, size and position of any focal lesion was recorded. It was determined that the presence of a hypodense lesion after contrast indicates the pituitary adenoma. Microadenoma was defined as a pituitary tumor with a diameter of less than $1 \mathrm{~cm}$ on any dimension whereas macroadenoma - with a size of at least one diameter more than $1 \mathrm{~cm}$. The MRI was qualified as equivocal if the pituitary tumor was not precisely visualized or only the indirect traits of the tumor were present such as the deviation of the pituitary stalk or a convex upper surface of the pituitary gland.

\section{Surgical procedure}

A microsurgical transseptal transsphenoidal approach was used for resection of an ACTH-secreting pituitary adenoma. The sella was exposed and an $\mathrm{H}$-shaped incision of the dura was made. Then the gland was carefully explored, regardless of MRI findings. Selective adenomectomy was performed in all cases of precisely visualized focal lesion on MR imaging. When the MR was equivocal or no tumor was evident, a series of vertical and horizontal incisions of the pituitary gland was carried out and all tissue deemed to be abnormal was removed and submitted for pathological examination. Hemihypophysectomy (compared to the corresponding site showing the MRI abnormality), subtotal hypophysectomy, or total hypophysectomy was performed for patients where no abnormal tissue could be identified intraoperatively.

\section{Histopathological and immunohistochemical assessment}

The surgical specimen was collected for histopathological analysis and routinely stained with hematoxylin and eosin. Immunohistochemical staining for pituitary hormones was performed according to the labelled EnVision Flex Visualization System (DAKO K8000). The result of histopathological analysis was considered "positive" if the presence of adenoma as well as the immunopositivity for ACTH was confirmed. The result was treated as "negative" if there was no histopathological evidence of the corticotrophic adenoma and ACTH-staining was negative.

\section{Postoperative hormonal evaluation and criteria of cure}

Blood samplesforserum cortisolmeasurementswerecollectedfrom all patients at 6.00 on the first postoperative day. Hydrocortisone replacement therapy was started after biochemical confirmation of hypocortisolemia or in case of the development of clinical symptoms of adrenal insufficiency. During the first two postoperative days the hydrocortisone was given intravenously in a daily dose $50 \mathrm{mg}$ t.i.d. Afterwards the standard dose of hydrocortisone $(20 \mathrm{mg}$ in the morning and $10 \mathrm{mg}$ at 15.00 ) was started and continued until the next hormonal evaluation. Following the surgical procedure all patients were subjected to further postoperative evaluation lasting at least 18 months (median 30 months; range 18 - 36 months).

The patients were regarded as cured if they fulfilled the following criteria for remission: subnormal serum cortisol on the $1^{\text {st }}$ postoperative day and (at the end of follow-up): clinical and biochemical evidence of eucortisolemia (morning serum cortisol between $5-25 \mu \mathrm{g} / \mathrm{dl}$ ), the normal circadian rhythm (the late night serum cortisol level $\leq 7.5 \mu \mathrm{g} / \mathrm{dl}$ ) and the ability of serum cortisol to suppress to less or equal than $1.8 \mu \mathrm{g} / \mathrm{dl}$ following the overnight 1 mg dexamethasone suppression test.

\section{Hormone assay}

Chemiluminescent immunometric assays (IMMULITE 2000; Siemens, Great Britain) were used to measure serum and urinary cortisol. Method sensitivity was $0.2 \mu \mathrm{g} / \mathrm{dl}(5.5 \mathrm{nmol} / \mathrm{l})$. The normal range for cortisol is $5-25 \mu \mathrm{g} / \mathrm{dl}(138-690 \mathrm{nmol} / \mathrm{l})$ whereas for UFC - 20 - $90 \mu \mathrm{g} / 24 \mathrm{~h}$. Plasma ACTH was measured using a specific twostep radioimmunometric assay (IRMA). The method sensitivity was $1.2 \mathrm{pg} / \mathrm{ml}$ and the referral range: $10-60 \mathrm{pg} / \mathrm{ml}$.

\section{Statistical analysis}

Methods of descriptive statistics (mean, median, standard deviations) were employed. Verification of hypotheses concerning the relationship between two categorical variables was expressed as frequencies and compared using the exact chisquare test (Fisher's exact test). The level of significance was set at $p<0.05$. The calculations were made using the statistical software package SPSS v. 18.0. 


\section{RESULTS}

The pituitary microadenoma was confirmed in 22 patients (61.1\%) whereas macroadenoma was found in 6 patients (16.7\%). The equivocal results of MR imaging was observed in 8 patients with Cushing's disease (22.2\%).

With reference to a group of 8 patients with equivocal MR results it was assumed that in their case ACTH-dependent Cushing's syndrome was caused by a very small $(1-3 \mathrm{~mm})$ in diameter pituitary microadenomas. Such small focal lesions remains outside the range of detection of even the most sensitive neuroradiological imaging methods. Therefore, being aware that in diagnostics of Cushing's disease the MRI results should be considered alongside with biochemical results, after confirmed diagnosis of Cushing's disease in hormonal evaluations, the patients were referred to the Department of Neurosurgery to consider undergoing the diagnostic sellar exploration.

Based on hormonal evaluation carried out on the 1st postoperative day and at the end of 18 months follow-up, 17 of 22 patients (77.3\%) with pituitary microadenoma precisely visualized in MRI were regarded as cured. In the subgroup of patients with macroadenoma the surgical treatment efficacy was lower - only 3 of 6 patients (50\%) were surgically cured. The lowest treatment efficacy was observed in the subgroup of patients with equivocal MRI results - the sustained remission was confirmed only in 3 of 8 patients (38.5\%).

Furthermore we verified the relationship between the surgical cure from Cushing's disease and results of preoperative tumor imaging. To achieve this, we compared a subgroup of patients with the "beneficial" feature, understood as precisely visualized pituitary microadenoma in MR examination with a subgroup of patients with an "adverse" feature. The latter included patients with pituitary macroadenoma as well as patients with equivocal MRI findings. Both "adverse" features were investigated together only due to the relatively small number of studied patients. In the Fisher's test the statistically significant difference was demonstrated between the cured and uncured subgroups with reference to preoperative MR imaging result $(p=0,036)$ (Table I).

\section{DISCUSSION}

Hitherto, there have been controversies in the literature concerning the importance of preoperative visualization of corticotroph adenomas and its impact on efficacy of surgical treatment. The multicenter retrospective analysis of Bochicchio et al. demonstrated that precise preoperative MR localization of a pituitary focal lesion is associated with greater efficacy of operative treatment and lack of such localization is associated with poorer prognosis. However, this analysis did not separately evaluate treatment efficacy in the subgroup of pituitary corticotroph micro- and macroadenomas (3).

Similar reports on the importance of preoperative MR imaging are presented by neurosurgical centers. According to their authors, the lowest percentage of remissions is observed in patients with normal or equivocal MR image $(5,6,12,16,18,20)$. In turn, a retrospective study of French authors, which excluded patients with pituitary corticotroph macroadenomas, did not confirm statistically significant difference between the cured and non-cured groups with reference to preoperative MR examination result (microadenoma vs. normal MR image). However, the authors admitted that the scope of performed surgery was greater in patients with a normal MR image, compared to patients with precisely localized pituitary microadenoma (19).

An interesting study of Woo et al., based on a retrospective assessment of 16 patients with pituitary macroadenoma demonstrated that treatment efficacy in this group of patients is low. Only 2 out of 16 patients were surgically cured $(12.5 \%)$ and another $5(31.3 \%)$ entered into remission after a subsequent radiotherapy (22). It should be stressed, that in our material the efficacy of operative treatment of patients with pituitary macroadenoma was higher and equaled as much as $50 \%$.

In the study by Fomekong et al. the efficacy of operative treatment in the subgroup of micro- and macroadenomas was similar ( $84 \%$ vs. $92 \%$, lack of statistical significance) and significantly greater than in the subgroup with noncharacteristic MR image, in which not a single patient was cured (8). This puzzlingly high frequency of Cushing's disease remission in patients with pituitary macroadenoma is probably associated with the fact that the authors did not have material with large invasive corticotroph tumors infiltrating adjacent structures. The mean, maximum size of pituitary macroadenoma reported in this study was $1.5 \mathrm{~cm}$ and the largest lesion was $2.5 \mathrm{~cm}$ in diameter. The results prove that the division of corticotropic tumors into microadenomas and macroadenomas based on the criterion of largest tumor size of $\geq 1 \mathrm{~cm}$ is only conventional in nature. It seems that macroadenomas of "intermediate" sizes between 1-1.5 cm, which are easily seen and do not infiltrate the surrounding structures may be relatively easier for an operator to completely remove, which is why efficacy of operative

Table I: Comparison Between the Cured $(\mathrm{N}=23)$ and Non-Cured $(\mathrm{N}=13)$ Subgroups by the Result of Preoperative MR Examination

\begin{tabular}{|c|c|c|c|c|}
\hline Neuroradiological evaluation result & Number of patients & $\begin{array}{l}\text { Cured patients } \\
\qquad(\mathrm{N}=\mathbf{2 3})\end{array}$ & $\begin{array}{l}\text { Non-cured patients } \\
\qquad(\mathrm{N}=13)\end{array}$ & $\mathbf{p}$ \\
\hline Pituitary microadenoma & $22(61.1 \%)$ & $17(73.9 \%)$ & $5(38.5 \%)$ & \\
\hline $\begin{array}{l}\text { Pituitary macroadenoma or equivocal } \\
\text { MR image finding }\end{array}$ & $14(38.9 \%)$ & $6(26.1 \%)$ & $8(61.5 \%)$ & $p=0.036$ \\
\hline
\end{tabular}


treatment of such lesions is similar in the microadenoma subgroup. Larger tumors (> $2 \mathrm{~cm}$ ) infiltrating the adjacent tissues, which practically were not present in the study of Fomekong et al. (and which are present in our study) must have poorer prognosis - which has been demonstrated in the presented own material. Most probably it is the infiltration degree of critical structures that prevents achievement of surgery completeness and thus recovery from Cushing's disease $(2,4,18,21)$.

When summarizing considerations on preoperative pituitary gland imaging in Cushing's disease one can state that precise magnetic resonance imaging increases efficacy of neurosurgical treatment in those cases, in which pituitary adenoma is precisely localized. It also seems that the best outcomes are achieved performing surgery on corticotroph microadenomas clearly visible in MR examination, and definitely worse outcomes are achieved in case of pituitary macroadenomas and patients with non-characteristic MR image.

\section{CONCLUSIONS}

The results of our prospective study indicate that precise visualization of a microadenoma in preoperative MR imaging of the pituitary may be regarded as one of beneficial prognostic factors increasing the probability of achieving surgical cure of Cushing's disease. On the other hand, presence of pituitary macroadenoma or equivocal results of preoperative MRI are related to decreased efficacy of surgical treatment.

\section{DISCLOSURE}

The authors declare no conflict of interest.

\section{FUNDING}

This study was supported by 501-2-1-07-12/07 CMKP grant.

\section{REFERENCES}

1. Biller BMK, Grossman AB, Stewart PM, Melmed S, Bertagna $X$, Bertherat J, Buchfelder M, Colao A, Hermus AR, Hofland LJ, Klibansky A, Lacroix A, Lindsay JR, Newell-Price J, Nieman LK, Petersen S, Sonino N, Stalla GK, Swearingen B, Vance ML, Wass JAH, Boscaro M: Treatment of adrenocorticotropindependent Cushing's syndrome: A consensus statement. J Clin Endocrinol Metab 93:2454-2462, 2008

2. Blevins Jr LS, Christy JH, Khajavi M, Tindall GT: Outcomes of therapy for Cushing's disease due to adrenocorticotropinsecreting pituitary macroadenomas. J Clin Endocrinol Metab 83:63-67, 1998

3. Bochicchio D, Losa M, Buchfelder M: Factors influencing the immediate and late outcome of Cushing's disease treated by transsphenoidal surgery: A retrospective study by the European Cushing's disease survey group. J Clin Endocrinol Metab 80:3114-3120, 1995

4. Cannavò S, Almoto B, Dall'Asta C, Corsello S, Lovicu RM, De Menis $\mathrm{E}$, Trimarchi F, Ambrosi B: Long term results of treatment in patients with $\mathrm{ACTH}$-secreting pituitary macroadenoma. Eur J Endocrinol 149(3):195-200, 2003
5. Chen JC, Amar AP, Choi S, Singer P, Couldwell WT, Weiss MH: Transsphenoidal microsurgical treatment of Cushing disease: Postoperative assessment of surgical efficacy by application of an overnight low-dose dexamethasone suppression test. J Neurosurg 98:967-973, 2003

6. Esposito F, Dusick JR, Cohan P, Moftakhar P, McArthur D, Wang C, Swerdloff RS, Kelly DF: Clinical Review: Early morning cortisol levels as a predictor of remission after transsphenoidal surgery for Cushing's disease. J Clin Endocrinol Metab 91: 7-13, 2006

7. Findling JW, Doppman JL: Biochemical and radiologic diagnosis of Cushing's syndrome. Endocrinol Metab Clin North Am 23:511-537, 1994

8. Fomekong E, Maiter D, Grandin C, Raftopoulos C: Outcome of transsphenoidal surgery for Cushing's disease:a high remission rate in $\mathrm{ACTH}$-secreting macroadenomas. Clin Neurol Neurosurg 111:442-449, 2009

9. Hammer GD, Tyrrell JB, Lamborn KR, Applebury CB, Hannegan ET, Bell S Rahl R, Lu A, Wilson CB: Transsphenoidal microsurgery for Cushing's disease: Initial outcome and longterm results. J Clin Endocrinol Metab 89:6348-6357, 2004

10. Hofmann BM, Fahlbusch R: Treatment of Cushing's disease: A retrospective clinical study of the latest 100 cases. Front Horm Res 34:158-184, 2006

11. Lahera Vargas $M$, da Costa CV: Prevalence, aetiology and clinical findings of Cushing's syndrome. Endocrinol Nutr 56(1): 32-39, 2009

12. Laws ER, Reitmeyer M, Thapar K, Vance ML: Cushing's disease resulting from pituitary corticotrophic microadenoma. Treatment results from transsphenoidal microsurgery and gamma knife radiosurgery. Neurochirurgie 48:294-299, 2002

13. Lindholm J, Juul S, Jørgensen JO, Astrup J, Bjerre P, FeldtRasmussen $U$ Hagen $C$, Jørgensen J, Kosteljanetz $M$, Kristensen L, Laurberg P, Schmidt K, Weeke J: Incidence and late prognosis of Cushing's syndrome: A population-based study. J Clin Endocrinol Metab 86:117-123, 2001

14. Lindsay JR, Nieman LK: Differential diagnosis and imaging in Cushing's syndrome. Endocrinol Metab Clin North Am 34(2):403-421, 2005

15. Nieman LK, Biller BMK, Findling JW, Newell-Price J, Savage MO, Stewart PM, Montori VM: The diagnosis of Cushing's syndrome: An endocrine society clinical practice guideline. J Clin Endocrinol Metab 93:1526-1540, 2008

16. Oldfeld EH: Cushing disease. J Neurosurg 98:948-951, 2003

17. Rees DA, Hanna FW, Davies JS Mills RG, Vafidis J, Scanlon MF: Long term follow-up results of transsphenoidal surgery for Cushing's disease in a single centre using strict criteria for remission. Clin Endocrinol(Oxf) 56(4):541-551, 2002

18. Reitmeyer $M$, Vance ML, Laws ER Jr: The neurosurgical management of Cushing's disease. Mol Cell Endocrinol 197:73-79, 2002

19. Salenave S, Gatta B, Pecheur S, San-Galli F, Visot A, Lasjaunias P Roger P, Berge J, Young J, Tabarin A, Chanson P: Pituitary magnetic resonance imaging findings do not influence surgical outcome in adrenocorticotropin-secreting microadenomas. J Clin Endocrinol Metab 89:3371-3376, 2004 
20. Semple PL, Vance ML, Findling JW, Laws ER: Transsphenoidal surgery for Cushing's disease: Outcome in patients with a normal magnetic resonance imaging scan. Neurosurgery 46:553-559, 2000

21. Storr HL, Afshar F, Matson M, Sabin I, Davies MK, Evanson J Plowman PN, Besser GM, Monson JP, Grossman AB, Savage MO: Factors influencing cure by transsphenoidal selective adenomectomy in paediatric Cushing's disease. Eur J of Endocrinol 152:825-833, 2005
22. Woo SY, Isidori AM, Wat WZ, Kaltsas GA, Afshar F, Sabin I Jenkins PJ, Monson JP, Besser GM, Grossman AB: Clinical and biochemical characteristics of adrenocorticotropin-secreting macroadenomas. J Clin Endocrinol Metab 90:4963-4969, 2005 